\title{
UČITELSKÉ VYHOŘENÍ V PERSPEKTIVĚ ŠKOLNÍCH PSYCHOLOGŮ
}

\author{
Anna Bartoňová \& Irena Smetáčková
}

\begin{abstract}
Abstrakt
Školní psychologové se dnes stávají běžnou součástí základních a středních škol. Podle platné vyhlášky by své služby na školách měli nabízet nejen žákům a jejich rodičům, ale také vyučujícím. Svým působením by měli usilovat o podporu učitelské profese vzhledem k jejím rizikovým faktorům. Učitelství je dnes totiž považováno za vysoce stresové povolání, v důsledku čehož lze očekávat, že vyučující jsou vysoce ohroženi syndromem vyhoření. Článek představuje kvalitativní výzkumnou studii zaměřenou na působení školních psychologů v oblasti učitelského vyhoření. Jejím cílem bylo zjistit, jak školní psychologové vnímají syndrom vyhoření a jakým způsobem přispívají k prevenci či samotnému řešení syndromu vyhoření u vyučujících na základních školách, kde působí. Studie se zúčastnilo 10 školních psycholožek a 1 psycholog, s nimiž byly prováděny rozhovory. Analýza ukázala, že zúčastněné školní psycholožky a psycholog vnímají syndrom vyhoření u vyučujících jako aktuální téma. Svým působením na školách přispívají k nespecifické prevenci syndromu vyhoření, ale nerealizují žádné specifické aktivity pro snižování a zvládání učitelského stresu. Ovšem s vyučujícími, které identifikují jako „vyhořelé“, intervenčně pracují.
\end{abstract}

Klíčová slova: školní psychologie, syndrom vyhoření, učitelé, prevence, intervence

\section{TEACHER'S BURNOUT SYNDROME IN PERSPECTIVE OF SCHOOL PSYCHOLOGISTS}

\begin{abstract}
Nowadays, school psychologists have become a standard part of primary and secondary schools. According to current law, they should provide their services to students and their parents as well as to teachers. They should support teachers considering them being higly susceptible to burnout syndrome. Teaching today is considered as a higly stressful job, so it is not suprising that they often suffer from burnout syndrome. This article contains qualitative research which is focused on a school psychologist's role in teacher's burnout syndrome. The aim was to discover how school psychologists perceive burnout syndrome and how they contribute to prevention or solving burnout syndrome itself at primary schools, where they work. 11 school psychologists were interviewed in presented study. The analysis has shown that the involved school psychologists perceive teacher's burnout syndrome as an actual topic. They contribute to the nonspecific burnout syndrome prevention but they do not implement any specific activities in order to lower the level of teacher's stress. On the other hand, they regularly work with teachers who they identify as ,burnout".
\end{abstract}

Keywords: school psychology, burnout syndrome, teachers, prevention, intervention

Došlo: 10. 10. 2019

Schváleno: 23. 6. 2020 


\section{Úvod}

Přestože se zvyšuje počet školních psychologo̊ำ ${ }^{1}$ etablování této pozice ve školách probíhá jen pozvolna. Nadále přetrvávají nejasnosti a odlišná očekávání ohledně jejich náplně práce (Štech \& Zapletalová, 2013). Podíl má na tom dozajista velká škála činností a potencionálních klientů, kterým se na škole věnují, a rovněž ambivalentní pozice školních psychologů ve školách, kde patří zároveň ke školnímu týmu, ale přitom stojí i částečně mimo něj. Různí autoři se pokoušeli o vymezení náplně školní psychologie (Čáp \& Mareš, 2001; Kavenská, Smékalová \& Šmahaj, 2011; Vágnerová, 2005) i o popis jednotlivých činností a úskalí této profese (Braun, Marková \& Nováčková, 2014; Štech \& Zapletalová, 2013; Zapletalová, 2001). Shodují se, že specifika školní psychologie vyplývají z její lokalizace do vzdělávacích institucí, které mají svébytné organizační principy dané svou funkcí a aktuálním postavením ve společnosti a současně rozkročeností poskytovaných poradenských služeb žákům, jejich rodičům a vyučujícím, přičemž každá z těchto cílových skupin má jedinečné (v některých ohledech protichůdné) potřeby a preferované formy komunikace. Tradičně bývá největší pozornost věnována práci školních psychologů s jednotlivými žáky a tř́́dními skupinami. V souvislosti s nimi jsou některé aktivity zaměřovány také na vyučující, protože ti s žáky dominantně komunikují. Učitelé jako cílová skupina však bývá v pozadí zájmu. Tento text představuje výsledky studie, která se zaměřila na to, zda a jak školní psychologové pracují s vyučujícími v oblasti prevence profesního stresu a syndromu vyhoření.

\section{Kontakt školních psychologů s vyučujícími}

Náplň práce školních psychologů je dnes legislativně ukotvena především ve vyhlášce č. 197/2016 Sb., kterou se měnilo znění vyhlášky č. 72/2005 Sb. Zde je vymezena jejich pracovní činnost ve vztahu $\mathrm{k}$ žákům, rodičům a vyučujícím, přičemž převaha činností směřuje $\mathrm{k}$ žákům a jen výrazná menšina $\mathrm{k}$ vyučujícím. Dle této vyhlášky by školní psychologové měli vyučujícím metodicky pomáhat (v rámci třídnických hodin, při práci se žáky se speciálními vzdělávacími potřebami apod.), poskytovat jim krizovou intervenci a individuální konzultace o výukových a výchovných problémech žáků. Dále by také měli vytvářet vzdělávací semináře pro pedagogické pracovníky.

$\mathrm{Na}$ základě zmíněné vyhlášky, existujících teoreticko-empirických publikací (Braun, Marková \& Nováčková, 2014; Štech \& Zapletalová, 2013; Zapletalová, 2014) i našich praktických zkušeností navrhujeme rozčlenit aktivity školních psychologů, které se vztahují k vyučujícím, z pěti hledisek. Jejich kombinací lze popsat všechny typy situací, kdy školní psychologové a vyučující přichází ve škole pracovně do kontaktu.

Prvním hlediskem je velikost, podle které rozlišujeme skupinové (napřr. semináře, supervize) a individuální aktivity (např. konzultace pro jednotlivce). Cúlem společných setkání může být metodická podpora, společné hledání řešení v problematické situaci, podpora vyučujících v náročných situacích a spolupráce při práci s trrídním kolektivem (diagnostika školních trríd, preventivní a intervenční programy atd.). Zmíněné činnosti mají společný základ, kterým je podpora učitelské profese. Druhým hlediskem je objekt, kterého se aktivita týká. Mohou jimi být konkrétní žáci, školní kolektivy, kvalita výuky, rodiče, kolegové nebo sami vyučující. Třetím hlediskem je téma školně-psychologických aktivit, přičemž jednotlivá témata mohou

${ }^{1} \mathrm{~V}$ celém textu budeme pro jednoduchost užívat pro označení profese mužský rod: školní psycholog, učitel i přesto, že $\mathrm{v}$ těchto profesích působí $\mathrm{z}$ velké části právě ženy. 
být vztažena k různým, výše zmíněným osobám a skupinám. Téma představuje druh řešeného problému, který se zejména může týkat bud' porozumění osobnosti, situaci či vztahu (tj. proč se dané dítě takto chová? Proč je ve třídě 6.A zvýšená nekázeň? Jak silný je můj profesní stres? atd.), nebo uvažování o možné změně (tj. jaké efektivnější způsoby učení můžou používat žáci s PAS? Co mohu dělat jinak, aby vztah s žákem XY nebyl konfliktní? Jak jinak můžu reagovat na profesní zátěž?). Čtvrtým hlediskem je bezprostřednost aktivit, která vede k rozlišení aktivit cíleně až formálně organizovaných (tj. aktivita je explicitně pojmenována a všem zúčastněným je znám její obsah i účel), aktivit spontánních (tj. aktivita se zrodí spontánně na pozadí jiných činností, avšak při jejím průběhu je všem zřejmá) a aktivit latentních (tj. aktivita probíhá bez plného vědomí zúčastněných osob, z nichž některým je její účel skrytý). Pátým hlediskem je původce aktivity. Kontakt s vyučujícími a konkrétní aktivitu s určitým obsahem a cílem může iniciovat bud' školní psycholog, nebo učitel, ale také například vedení školy, rodiče, studující či kolegové. $V$ tomto př́padě je však na místě úvaha nad efektivitou požadovaných aktivit ve chvíli, kdy nepramení od samotného učitele, ale např́klad od vedení školy či kolegů a to především ve chvíli, kdy se jedná o psychickou pohodu samotného vyučujícího. Pokud je původcem aktivity někdo jiný než samotný učitel, je možné, že taková situace povede k „Zablokování“ konkrétního učitele. Vždy je proto potřeba zvážit danou situaci vzhledem $\mathrm{k}$ povaze konkrétního učitele a vztahu mezi ním a školním psychologem.

V našem výzkumu se věnujeme těm typům aktivit, které jsou zaměřeny na samotné vyučující (hledisko 2). Ve vztahu k dalším zmíněným hlediskům nás ve výzkumu zajímá, jak o aktivitách pro vyučující školní psychologové uvažují, které typy kombinací v dalších kritériích použivají a u kterých př́ípadně vnímají překážky, a to vždy ve vztahu k prevenci profesního stresu a syndromu vyhoření (hledisko 3).

Aby byly zmiňované aktivity úspěšné, musí mezi vyučujícími a školními psychology existovat dostatečná důvěra. Podle Zapletalové (2014) napomáhá k vybudování důvěry způsob komunikace, neformální setkávání (např. během obědů či ve sborovně) a nehodnotící prrístup k učitelské práci. Jako prospěšné se podle Zapletalové (2014) ukazuje aktivní oslovování vyučujících, osobní informování a práce v malých skupinách, přičemž školní psychologové musí být vůči vyučujícím otevření a trpěliví. Štech a Zapletalová (2013) dodávají, že vyučující pozitivně u školních psychologů vnímají jejich předchozí dlouholetou poradenskopsychologickou praxi a zkušenost s vlastní pedagogickou činností. Nápomocné bývá, pokud vyučující již mají předchozí zkušenost s psychologickými službami a mohou si tedy lépe uvědomit jejich prínos.

Důvěryplný vztah je důležitou podmínkou pro všechny typy zakázek, které vyučující se školními psychology mohou řešit. Zvláště klíčové jsou však v prrípadě témat, která se týkají osobnosti a profesní identity vyučujících, při jejichž řešení musí být vyučující dostatečně otevření k hlubší osobnostní změně (nejen ke změně kontrolovaných pedagogických postupů). Do této oblasti patří také zvládání pracovního stresu na pozadí hodnotové orientace a distribuce energie mezi jednotlivými životními sférami. Dlouhodobé problémy v této oblasti obvykle vyústí v syndrom vyhoření. Vzhledem k tomu, že se jedná o „intimnějšíc téma, než například neprospěch konkrétního žáka ve trrídě, je zřejmé, že je také náročnější se $k$ tomuto tématu s vyučujícím dopracovat a efektivně mu v něm pomoci. Vyučující může dokonce vnímat prostředí školy jako nevhodné k řešení takového problému. Školní psycholog mu však může nabídnout velké pochopení a podporu díky tomu, že prostředí a aktéry v něm dobře zná. 


\section{Syndrom vyhoření u vyučujících}

Syndrom vyhoření představuje stav intenzivního psychického a fyzického vyčerpání, který je důsledkem nadměrné pracovní zátěže, v níž jedinec zažívá trvalý a silný stres (Maslach, Jackson \& Leiter, 1996). V aktuální 11. verzi Mezinárodní klasifikace nemocí, která byla přijata $\mathrm{v}$ roce 2019 , byl syndrom vyhoření přeřazen mezi tzv. pracovní fenomény a je definován jako syndrom „vycházející z chronického pracovního stresu, který nebyl úspěšně zvládnutý (World Health Organization, 2019). Vyznačuje se: 1) pocity vyčerpání energie; 2) zvýšením psychické distance od práce nebo pocity negativismu či cynismu související s prací; a 3) sníženou pracovní efektivitou." V konečné podobě se syndrom vyhoření projevuje na třech úrovních: 1) psychické, jako je např. emoční vyčerpanost, pocity beznaděje, negativistické chování; 2) fyzické, jako je např. rychlá unavitelnost, bolesti hlavy, svalů, poruchy spánku; 3) sociálních vztahů, jako je např. pokles empatie, nárůst konfliktů, apatie k druhým (Kebza \& Šolcová, 2003; Shirom \& Melamed, 2006).

Nejčastěji se syndrom vyhoření projevuje v pomáhajících profesích, mezi které patří také učitelství. České výzkumy ukazují zhruba 10-20\% prevalenci vyhoření mezi vyučujícími na základních školách (Kusák \& Urbanovská, 2009; Žídková \& Martinková, 2003). Nejnovější výzkum na souboru 2394 učitelek a učitelů ZŠ došel k závěru, že 19 \% z nich vykazuje př́znaky vyhoření a dalších 65 \% je ohroženo vznikem vyhoření (Smetáčková et al., 2019). Učitelské vyhoření představuje zásadní problém jak pro profesní spokojenost, tak pro kvalitu pedagogické práce. Výzkumy prokazují, že vyhořelí vyučující mají výrazně horší vztahy s žáky, jejich výuka je méně záživná, nevěnují se profesnímu seberozvoji a nejsou schopni efektivní spolupráce v učitelském sboru (Brackett, M. A., Palomera, R., Mojsa-Kaja, J., Reyes, M. R., \& Salovey, P., 2010; Hastings \& Bham, 2003). Současně, vyhořelí vyučující se cítí nespokojeni, trpí psychickými problémy a mají řadu zdravotních negativních projevů.

Podstatou pomáhajících profesí, včetně učitelství, je intenzivní kontakt s druhými lidmi (Maslach, Jackson, \& Leiter, 1996). Ten sám o sobě bývá zdrojem stresu, což potvrdily zahraniční (Brackett, M. A., Palomera, R., Mojsa-Kaja, J., Reyes, M. R., \& Salovey, P., 2010; Poschkamp, 2013) i české výzkumy učitelských stresorů (Holeček, 2001; Kohoutek \& Řehulka, 2011), které shodně identifikovaly vztahy s dětmi, rodiči a kolegy mezi hlavními příčinami prožívaného stresu. Zdroje stresů lze schematicky rozdělit do tří skupin (Smetáčková, Vondrová \& Topková, 2017). První skupinu tvoří vztahy s žáky, rodiči a kolegy. Druhá skupina stresorů se týká pracovních podmínek (napr. velikost třídy, vybavení pomůckami, rozvrh) a dotýká se soustředění, flexibility a kreativity, které jsou třeba k naplnění podstaty učitelství. Třetí skupina stresorů pak zahrnuje školský a společenský kontext, tj. např́iklad prestiž či finanční ohodnocení.

Míra, v jaké vyučující proživají stres, závisí jednak na stresorech, které jsou součástí vnějších podmínek, a jednak na osobnosti daného jedince (Stock, 2010). Osobnost je pro riziko vzniku vyhoření významná nejen z hlediska rysů (napr. neuroticismus nebo perfekcionismus zvyšuje náchylnost $\mathrm{k}$ prožívání stresu), ale také z hlediska př́stupu k interpretaci událostí a strategií zvládání stresu. Ke shodným podnětům mohou různí jedinci přistupovat odlišně, a tedy i shodné stresory (např. žákovská nekázeň) může u různých vyučujících v závislosti na jejich osobnostních rysech a copingových strategiích vyvolávat odlišnou míru stresu. Efektivní prevence syndromu vyhoření předpokládá, že vyučující dobře znají sami sebe a jsou si vědomi svých preferovaných reakcí na stres i jejich účinnosti (Awa, Plaumann \& Walter, 2010). 


\section{Školní psychologie a syndrom vyhoření u učitelů}

Jak bylo uvedeno výše, podle platné vyhlášky mají školní psychologové poskytovat vyučujícím metodickou podporu, průběžné konzultace k potřebným tématům a krizovou intervenci. Ačkoliv se ve vyhlášce explicitně nehovoří o pomoci při zvládání profesního stresu a prevenci syndromu vyhoření, má spolupráce mezi vyučujícími a školními psychology tento potenciál. Na to upozorňují Braun, Marková a Nováčková (2014), podle kterých je pro prevenci syndromu vyhoření klíčová psychohygiena vyučujících, a apelují, aby školní psychologové zlepšovali psychohygienu učebního procesu nejen z hlediska žáků, ale také pedagogů. Dodávají, že o syndromu vyhoření a psychohygieně mohou školní psychologové poskytnout přednášku či preventivní aktivity nebo nabídnout pomoc konkrétním vyučujícím.

Impuls ke konání školně-psychologických aktivit pro jednotlivé vyučující či celé sbory může přicházet od vedení školy. Zelinová (1998) zdůrazňuje, že pracovníci školského managementu by měli usilovat o pravidelné monitorování psychického stavu vyučujících a více se zajímat o prríčiny zvyšující se zátěže vyučujících. Na základě výsledků pak mohou zorganizovat či alespoň vytvořit podmínky pro určitý typ formální či neformální aktivity určené vyučujícím a využívající přítomnost školního psychologa na škole. Například se může jednat o týmové supervize či intervize, které představují účinný nástroj pro zvýšení sebereflexe jednotlivých vyučujících, uvolnění negativních emocí, získání korektivní zkušenosti a prohloubení spolupráce $\mathrm{v}$ učitelském sboru, přičemž $\mathrm{v}$ obou př́padech se jedná o prevenci syndromu vyhoření. Jinou možností je strukturovaný vzdělávací program v oblasti, která se ukázala být slabinou dané školy. Např́klad Kipps-Vaughan (2013) popisuje zavedení tzv. stress management programu na americké škole, jehož cílem bylo snížit prožívaný stres u vyučujících a jeho důsledky v podobě častých absencí, předčasných odchodů do důchodu a syndromu vyhoření. Součástí programu byly aktivity na pozitivní myšlení, komunikaci, relaxaci, řešení problémů atd. Program se celkově potvrdil jako prŕnosný a napomohl posílení vzájemné podpory mezi kolegy, snížení pracovního stresu a úrovně somatických obtíží, přispěl také ke zvýšení osobního výkonu a celkové spokojenosti v práci.

\section{Představení výzkumu}

Učitelství je povolání s vysokým výskytem stresu a syndromu vyhoření (Brackett, M. A., Palomera, R., Mojsa-Kaja, J., Reyes, M. R., \& Salovey, P., 2010; Maslach, Jackson \& Leiter, 1996.; Smetáčková et al., 2019), což negativně dopadá na spokojenost vyučujících i na kvalitu jejich pracovního výkonu. Školní psychologové a vyučující nutně přicházejí do kontaktu a pokud spolupracují, může to mít pozitivní efekt na míru prožívaného učitelského stresu, profesní spokojenost a riziko syndromu vyhoření. Otázkou však je, nakolik se školní psychologové věnují (mají možnost věnovat) aktivitám, které vedou k prevenci vyhoření, a př́ípadně, jaké druhy aktivit to jsou.

Cílem zde prezentované studie bylo zjistit, jak školní psychologové přistupují k učitelskému vyhoření a které aktivity v oblasti prevence a intervence realizují. Tomuto cíli odpovídaly výzkumné otázky: 1) Jak školní psychologové vnímají riziko syndromu vyhoření u vyučujících na základních školách?; 2) Jak školní psychologové přistupují k prevenci učitelského vyhoření?; 3) Jak školní psychologové pracují s vyučujícími, u kterých identifikovali nastupující či rozvinutý syndrom vyhoření? (Bartoňová, 2019). 


\section{Výzkumné metody}

Studie využívala kvalitativní metodologii. Sběr dat probíhal prostřednictvím polostrukturovaného rozhovoru se školními psychology na základních školách. Struktura rozhovoru vycházela z odborné literatury pojednávající o školní psychologii a syndromu vyhoření (Braun, Marková \& Nováčková, 2014; Štech \& Zapletalová, 2013; Zapletalová, 2014) a byla pilotně ověřena. Pořadí a znění otázek se měnilo podle průběhu konkrétního rozhovoru, důraz byl kladen na perspektivu dotazované osoby tak, aby byly zohledněny přirozené podmínky a vztahy v jejím prostředí (Miovský, 2006).

Rozhovory probíhaly během roku 2018 a konaly se v kanceláři školního psychologa, ve dvou př́padech v kavárně a jednou v domácím prostředí. Rozhovory trvaly od 45 do 90 minut. Před jejich začátkem byli informanti seznámeni s cílem výzkumu a s plánem rozhovoru. Zároveň byli požádáni o souhlas s nahráváním rozhovoru na diktafon. Pouze v jednom př́padě byl vysloven nesouhlas. Tento rozhovor byl ručně zapisován na papír a nejedná se tak o doslovný přepis, jako je tomu u ostatních rozhovorů.

Přepsané záznamy rozhovorů byly podrobeny kvalitativní analýze. Nejprve proběhlo otevřené kódování ( $\mathrm{k}$ jednotlivým výrokům byly přiřazovány kódy, ze kterých byly postupně vytvářeny kategorie) a následně axiální kódování (mezi kategoriemi byly hledány vzájemné vazby). Analýza dat vycházela zejména z principů tematické analýzy (Braun \& Clarke, 2006). Výsledky analýzy jsou prezentovány $\mathrm{v}$ dílčích kapitolách podle hlavních identifikovaných témat a s ilustrativními citacemi. Jména informantů byla $\mathrm{z}$ důvodu anonymity upravena.

\section{Výzkumný soubor}

Výzkumný soubor byl vybrán pomocí záměrného výběru. Školní psychologové byli vyhledáni a osloveni na základě následujících kritérií: 1) Absolvování magisterského studia oboru psychologie, pracovní úvazek 0,5 a vyšší; 2) Délka praxe minimálně 1 školní rok; 3) Působení na základní škole. Základní charakteristiky zúčastněných osob znázorňuje tabulka 1.

Tab. 1: Základní charakteristiky školních psychologů ve výzkumu

\begin{tabular}{|c|c|c|c|c|c|}
\hline Jméno & $\begin{array}{l}\text { Velikost } \\
\text { úvazku }\end{array}$ & $\begin{array}{l}\text { Počet } \\
\text { zaměstnání jako } \\
\text { školní psycholog }\end{array}$ & $\begin{array}{l}\text { Počet let } \\
\text { působení } \\
\text { na aktuální } \\
\text { škole }\end{array}$ & Délka praxe & $\begin{array}{l}\text { Velikost a } \\
\text { lokalizace školy }\end{array}$ \\
\hline Marie & 0,5 & 1 & 1 & $\begin{array}{l}\text { Krátká } \\
(0-3)\end{array}$ & $\begin{array}{l}\text { Velká (nad } 600 \text { žáků), } \\
\text { velké město }\end{array}$ \\
\hline Petr & 1 & 2 & 3 & $\begin{array}{l}\text { Dlouhá } \\
\text { (6 a více) }\end{array}$ & $\begin{array}{l}\text { Velká (nad } 600 \text { žáků), } \\
\text { velké město }\end{array}$ \\
\hline Magda & 0,75 & 2 & 1 & $\begin{array}{l}\text { Dlouhá } \\
\text { (6 a více) }\end{array}$ & $\begin{array}{l}\text { Velká (nad } 600 \text { žáků), } \\
\text { velké město }\end{array}$ \\
\hline Lenka & 0,75 & 3 & 2 & $\begin{array}{l}\text { Dlouhá } \\
\text { (6 a více) }\end{array}$ & $\begin{array}{l}\text { Středně velká } \\
\text { (do } 600 \text { žáků), } \\
\text { okrajová část } \\
\text { velkého města }\end{array}$ \\
\hline Monika & 1 & 1 & 4 & $\begin{array}{l}\text { Středně dlouhá } \\
(3-6)\end{array}$ & $\begin{array}{l}\text { Malá (do } 300 \text { žáků), } \\
\text { velké město }\end{array}$ \\
\hline Andrea & 1 & 1 & 4 & $\begin{array}{l}\text { Středně dlouhá } \\
(3-6)\end{array}$ & $\begin{array}{l}\text { Velká (nad } 600 \text { žáků), } \\
\text { okrajová část velkého } \\
\text { města }\end{array}$ \\
\hline
\end{tabular}




\begin{tabular}{|l|c|c|c|l|l|}
\hline Pavlína & 0,5 & 1 & 2,5 & $\begin{array}{l}\text { Krátká } \\
(0-3)\end{array}$ & $\begin{array}{l}\text { Velká (nad 600 žáků), } \\
\text { velké město }\end{array}$ \\
\hline Kateřina & 1 & 2 & 10 & $\begin{array}{l}\text { Dlouhá } \\
(6 \text { a více })\end{array}$ & $\begin{array}{l}\text { Středně velká } \\
(\text { do } 600 \text { žáků), velké } \\
\text { město }\end{array}$ \\
\hline Justýna & 1 & 1 & 2,5 & $\begin{array}{l}\text { Krátká } \\
(0-3)\end{array}$ & $\begin{array}{l}\text { Velká (nad 600 žáků) } \\
\text { malé město }\end{array}$ \\
\hline Karolína & 0,5 & 1 & 1 & $\begin{array}{l}\text { Dlouhá } \\
(6 \text { a více })\end{array}$ & $\begin{array}{l}\text { Velká (nad 600 žáků) } \\
\text { malé město }\end{array}$ \\
\hline
\end{tabular}

\section{Výsledky}

\section{Aby mohla být navázána spolupráce...}

Všichni školní psychologové zdůrazňovali, že pro navázání spolupráce s vyučujícími je v prvé řadě potřeba získat si jejich důvěru. Při budování důvěry vnímají jako stěžejní neformální setkání - společné obědy, společné posezení u piva či zastavení se na chodbě na kus řeči. Magda k tomu uvedla: Že se tady po té škole pohybuju, že se s nimi nějak bavím, že se o ně zajímám, že o nich něco vím, že s nimi jdu třeba na oběd nebo na svačinu. Takže to je takový to první, nějak s nimi komunikovat. Justýna popsala: Snažila jsem se zúčastňovat takových těch akci pro všechny učitele, jako vánoční posezení apod. Jednak jsem chtěla být součástí té školy, jednak jsem si ř́kala, že je důležitý, abych byla ta jejich kamarádka, ke které mají důvěru. Magda, Justýna i ostatní považovali za podmínku, aby se mohl vytvořit ze strany vyučujících pocit důvěry, že jsou s nimi v průběžném kontaktu a v běžné komunikaci, kdy vyjadřují svůj profesní, ale i osobní zájem o vyučující. Aby projevovaný zájem skutečně vedl k navázání důvěry, musí působit autenticky. A proto je nezbytný bazální respekt. Všichni zúčastnění školní psychologové zdůrazňovali, že si vyučujících váží a pokládají za důležité jim projevovat respekt a úctu, díky čemuž k nim vyučující získají náklonnost a důvěru a cítí se bezpečně i v případě řešení nepř́ijemných situací.

Budování důvěry pokládají informanti za dlouhodobý proces. Zdůrazňovali, že s jeho délkou je třeba počítat a neuspěchat to. Jana to shrnuje následovně: Určitě jsem otevřená, dost se o ně jako zajímám. Taky (je to dáno) nějakým časem. To se musí navázat jako nějaká důvěra. V rozhovorech školní psychologové akceptovali, že v navazování vztahu s vyučujícími musí být iniciativnější a opakovaně musí dělat ,první krok“. Tuto asymetrii zdůvodňovali tím, že vyučující mají nedostatek času, ale také pocit’ují vzdálenost až bariéru mezi učitelskou a psychologickou pozicí a z ní vyplývající obezřetnost, která narůstá při nejasném organizačním zařazení psychologa na škole, a tedy z jeho potenciální blízkosti k vedení školy. Informanti se shodovali, že je potřeba být v navazování kontaktu aktivní a vytrvalý, než dojde k navázání vztahu, a předjímat obavy, které vyučující mohou od spolupráce se školním psychologem odrazovat, a snažit se jim porozumět. To demonstrovala Magda, když popisovala tzv. testovací fázi: Pak mi přijde, že je taková ta chvíle, kdy vás testují, jestli vám můžou věřit nebo ne, a tak vás třeba osloví s něčím, co není až tak, co až tak nehoři. To dělají i gymplácký děti. Taková fáze testování. Tak na tom si ozkoušej, jak fungujete a když se jim zdá, že jako dobrý, že to $s$ vámi jde, tak začnou pricházet s těma podstatnějšima, opravdovějšima témata. Je to takový postupný proces. 
Jaká bývá učitelská odezva na snahu o kontakt, je podle informantů ovlivněno řadou faktorů. Jako zásadní se jim jeví dosavadní zkušenost $\mathrm{s}$ aktuálně působícím školním psychologem, např́iklad na základě konzultace ohledně žáka, práce se tř́idou apod. Zdůrazňovali ale také vliv předchozí pozitivní zkušenosti vyučujících s jinými lidmi na pozici školního psychologa a př́ípadně vliv zprostředkované zkušenosti od kolegů (tedy vyprávění o užitečném setkání či zásahu školního psychologa). Díky tomu si vyučující vytvoří představu, co školněpsychologická pozice obnáší, jaký typ přínosu od ní mohou očekávat a jaký druh komunikace mají volit. Získání základní orientace přitom může vést k odbourání části bariér, které mohou spolupráci bránit. Chybějící či nejasná očekávání totiž omezují učitelskou ochotu vstoupit se školním psychologem do kontaktu. V př́ípadě osobní zkušenosti se současnou osobou na pozici školního psychologa se navíc zapojí i první dojem z druhého člověka, který je-li pozitivní, může tendence ke kontaktu posílit. Avšak je třeba doplnit, že osobní sympatie, ačkoliv může být nápomocná, není podle informantů nezbytnou a dostatečnou podmínkou pro vzájemnou spolupráci, protože jak vyučující, tak oni sami jsou profesionálové. Magda popsala, jak je podstatné získat vlastní zkušenost: Myslím si, že spousta z nich (vyučujících) z toho má obavy. Je důležité ziskat tu zkušenost. Až ziskaji tu zkušenost, že ode mě se toho nedočkají (vyzrazeni), tak teprve prijjou. Pavlína zmínila pozitivní vliv zkušenosti práce se třídou: Já si myslím, že částečně jsem jako získávala tu jejich důvěru, jak mě viděli pracovat s jinými tř́dami a jak chodím za jinými učiteli, a že jsme se jako potkávali na obědě...

Pokud je vztah mezi psychologem a učitelem vytvořen, mohou spolu efektivně řešit různé typy problémů týkajících se žáků, tříd či rodičů. Podle informantů se ale i v př́padě efektivních vztahů podstatně méně často řeší témata profesní spokojenosti, profesní zátěže a celkově osobních pocitů vyučujících. Zúčastnění školní psychologové velmi citlivě vnímali překážky, které na straně vyučujících brání, aby byli otevřeni tématům, které zasahují jejich profesní identitu. Mezi zmiňovanými důvody zdůrazňovali zejména nedostatečnou motivaci vyučujících, dále nedostatečnou sebereflexi a neschopnost náhledu na své problémy a také osobnostní nastavení, kdy vyučující s uzavřenější povahou neradi řeší své potíže s kýmkoliv. To popsala Monika: Část z nich je asi taková, jestli by vůbec méli tu potřebu, anebo i kdyby ji měli, jestli by jí využili. Třeba jsou fakt přiliš uzavření. Ted' mě napadají takový dva učitelé, protože je nás tu fakt málo. Prostě jim není vlastní řešit svoje problémy s někým jiným, takže tam asi kdyby se cokoliv dělo, tak by nepřišli a nechtěli by o tom mluvit. Informanti dále upozorňovali na překážky související s osobou školního psychologa, který může působit na daného učitele nesympaticky, případně příliš mladě a nezkušeně. Jako překážku vnímali také určité klima školy a přístup vedení. Konkrétně podle nich záleží na tom, jak otevřeně se na škole prristupuje $\mathrm{k}$ řešení problémů a zda sdílení pochybností či žádosti o pomoc není považováno za profesní nedostatek. Takovou zkušenost ze školy popsala polovina školních psychologů, mezi nimi také Jana: Ta škola je primárně zaměrená na chybu, takže učitelé to berou jako nějaké své selhání, jako že by se sebeodhalili, ukázali nějakou svou chybu. Ale která vlastně není chyba.

\section{Učitelské vyhoření je...}

Z rozhovorů vyplynulo, že zúčastnění školní psychologové vnímají syndrom vyhoření u vyučujících jako aktuální téma, a to jak v učitelství obecně, tak konkrétně na školách, kde působí. V devíti případech si jsou přímo jisti, že součástí učitelských sborů, s nimiž pracují, jsou „vyhořelí“ či k vyhoření směřující učitelé. Pouze dvě psycholožky uvedly, že vyhoření 
na jejich školách není (vážný) problém. Jednalo se o Karolínu a Moniku, které působily na školách, které se lišily svým typem od zbytku souboru (malá škola, na malém městě, prostředí otevřené ke sdílení).

Samotné učitelství vnímají školní psychologové jako vysoce rizikové povolání. Jeho náročnost spatřují v problémovém chování žáků a rodičů, nadbytečné administrativě, nedostatečném ocenění, narůstajících požadavcích vedení škol, nedostatečné podpoře kolegů a velkém počátečním nadšení. Právě kumulace nároků a jejich momentální nárůst je podle zúčastněných osob hlavním důvodem, proč se riziko učitelského vyhoření zvyšuje. Justýna vyjmenovala následující sérii faktorů: $V$ dnešni době se ale opravdu náročnost profese zvedá. Nutnost diferencovat - ale nevím jak? Větši nároky od rodiču. Málo učitelü - musejí učit $i$ angličtinu, $i$ když sami ji neumějí a nemají rádi. Hodně papírování. Malá prestiž.

Ačkoliv dvě psycholožky neměly ze svého současného působiště zkušenost s vyučujícími, kteří vykazují projevy vyhoření, všichni pojmenovali četné prř́znaky syndromu vyhoření. Jedná se podle nich o vyčerpanost, podrážděnost, celkovou ztrátu nadšení a časté somatické obtíže. Těchto symptomů si snaží všímat u vyučujících, s nimiž pracují. Dělají to v rámci průběžného monitorování situace ve škole, kterému se podle svých slov věnují všichni informanti. To zahrnuje pozorování změn v chování jednotlivých vyučujících, pozorování atmosféry v kabinetech a naslouchání tomu, co vyučující říkají. To popisuje například Monika: Já to nejvíc asi sleduju, a když bych asi viděla nějaký náznak toho, že je ten učitel v poslední době nějaký zasmušilý a tak dále, tak to by byl asi nějaký impulz nebo podnět, abych se na to nějak zaměřila. Žádná ze zkoumaných osob neuvedla, že by při zjištění negativní atmosféry či změn v chování prováděla cílený a strukturovaný sběr dat, a to ani o učitelském stresu a vyhoření, ani o profesní spokojenosti. Zúčastněné osoby nedisponují žádnými diagnostickými nástroji (např. dotazníky) a ani jejich využívání nevnímají jako přínosné, a to zejména proto, že vyučující jsou podle nich zahlcení vyplňováním dotazníků od školy a dalších institucí, a je proto náročné je přesvědčit o „smysluplnosti dalšiho vyplňováni“.

\section{Aby učitelské vyhoření nenastalo...}

Navzdory našemu očekávání rozhovory ukázaly, že zúčastnění školní psychologové nevnímají prevenci syndromu vyhoření jako součást své agendy. Tedy ani nepovažují za nezbytné systematicky mapovat učitelský stres a profesní ne/spokojenost. Na druhou stranu ale do své agendy shodně zařazují jednak metodickou podporu a jednak pomoc vyučujícím v náročných situacích. Metodickou podporu nejčastěji poskytují formou individuální konzultace, práce se třídou, náslechy ve tř́dách, semináři, workshopy či supervizním setkáním. Pomoc v náročné situaci nejčastěji poskytují formou individuální konzultace, mediace nebo supervizního setkání . Jak uváděli sami informanti, vedlejším efektem všech uvedených aktivit může být právě prevence učitelského vyhoření. Nijak cíleně se však na syndrom vyhoření nezaměřují. Jsou ovšem přesvědčeni, že pouhou svou přítomností na škole, opakovanou nabídkou pomoci a projevováním zájmu o jednotlivé vyučující působí preventivně, tedy snižují riziko syndromu vyhoření. Vědomí toho, že je na škole někdo, kdo je ochoten pomoci, je totiž podle nich samo o sobě úlevné. Kateřina například popsala svůj přístup takto: Jako záměrně, plánovitě, že bych se třeba rozhodla je poučit o syndromu vyhoření, tak to ne. Nedělám asi nic cíleně. Spíš to, že tu jsem, že se mnou mohou sdílet, to taky nějakým způsobem působí preventivně. 
Silný preventivní potenciál informanti zdůrazňovali především u individuálních konzultací. Ty slouží především k řešení problémů týkajících se žáků, trríd a rodičů. Někdy je ale vyučující využívají i ke sdílení osobních problémů, jako jsou partnerské neshody či starosti s vlastními dětmi. Školní psychologové se shodovali na tom, že během individuálních konzultací poskytují především prostor $\mathrm{k}$,postěžování si““ a vyjádření negativních emocí, zároveň se ale také snaží vyjádřit pochopení a podporu v náročné situaci. To zdůraznil např́iklad Petr: Přijdou, řeknou si, co potřebují, třeba že je někdo naštval a pak si tu hodinu povídáme. Někdy se sem prostě přijdou uklidnit, postěžovat si... Většinou se potřbují poradit nebo jen najít prostor, kde se v klidu můžou vyvztekat. A takový misto je tady u mě...

Další aktivitou s preventivním potenciálem, kterou však uvádělo jen několik psychologů, je braní konkrétních žáků z výuky. Cílem je odlehčit vyučujícímu v jeho práci a předejít vzniku možných konfliktů mezi ním a žákem. Jinou potenciálně preventivní aktivitou (resp. skupinou aktivit), kterou školní psychologové pro vyučující organizovali, jsou výjezdy, semináře a supervize. Organizátorkou individuálních supervizí je např́ílad Justýna, která k tomu vysvětluje: Založila jsem tam externí supervize, což si myslím, že je velká podpora pro ty učitele. Takže k nám chodil externí supervizor, měl nejdřiv mě a pak ještě 3 učitele. Jejich hlavním cílem je zvyšovat obecně psychickou pohodu vyučujících. Pravděpodobně pod vlivem rozhovoru ale informanti uvedli, že tyto aktivity mohou mít za cíl i prímo prevenci syndromu vyhoření.

Školní psychologové se také zamýšleli nad určitými preventivními opatřeními, které by rádi zavedli v budoucnu. Uváděli např́íklad, že by plánovali vést supervize, zavést pravidelné zhodnocování vlastní práce vyučujícími či pravidelné lekce jógy. Momentálně však vnímají překážky, proč není možné návrhy realizovat. Např́klad Magda, která uvažovala o zavedení supervizních setkání, vnímá překážku v kvalitě vztahů s učitelským sborem: Do čeho jsem se zatím tady nepustila a dělala jsem to na predchozi škole, tak to byly setkání pro učitele, ale mám pocit, že tam je potřeba nejdřiv získat tu důvěru těch učitelů, a pak s tím teprve začit. Ted' už mám pocit, že ta dưvěra je vybudovaná u těch učitelü, takže ted' už bych si na to troufla, ale ten první rok bych to určitě nedělala. Nedostatečná důvěra byla považována za hlavní problém při zavádění na sdílení zaměřených aktivit. U dalších druhů aktivit byly zmiňovány jako překážky nedostatečná podpora vedení a omezené odborné zkušenosti.

\section{Když už syndrom vyhoření vypukne...}

Devět dotazovaných školních psychologů se domnívalo, že se na ně vyučující obrátí, pokud se budou cítit profesně nespokojení či vyhořelí. Nejsilnější přesvědčení deklaroval Petr: Přijdou určitě, to mě těší. Ostatních osm psychologů vnímalo (byt' v různé míře), že pro některé vyučující, ačkoliv jsou ohroženi syndromem vyhoření, není kontakt se školním psychologem akceptovatelný. Dva psychologové zase měli jasno v tom, že se na ně vyučující v této oblasti neobrátí. Pavlína např́klad uvedla: Myslím si, že asi ne (neobrátí se na ni). Protože si myslím, že nějaký vyučujicí tam máme, co se k tomu (k vyhořeni) bliži a furt nikdo nezaklepal. Přesvědčení, že se vyučující na školního psychologa v př́ípadě potřeby obrátí, variovalo z hlediska několika profesních znaků. Zejména se jednalo o míru zkušeností a velikost úvazku. Psychologové s krátkou psychologickou praxí ( 0 až 3 roky) a pracující na škole pouze na 0,5 úvazku, se shodně domnívali, že se na ně vyučující neobrátí. Společným znakem těchto psychologů navíc bylo, že se ve své praxi orientují především na děti. Můžeme se tak domnívat, 
že délka psychologické praxe (zprostředkovaně i věk) a současně malý pracovní úvazek ovlivňují budování důvěry, která je podstatná pro navázání spolupráce s vyučujícími.

Všichni informanti v rozhovoru uváděli, že pokud (by) identifikovali u některého učitele syndrom vyhoření, snažili (by) se aktivně navrhovat řešení. Postup je podle nich velmi individuální - záleží na okolnostech dané situace a osobnosti jedince. Obecně se informanti shodli na tom, že pokud vnímají, že je nějaký vyučující profesně nespokojený nebo dokonce vyhořelý, jdou za ním, osloví ho a projeví o něj starost. Následně mu nabídnou možnost konzultace. Tento průběh popsala naprríklad Magda: No, tak já bych za nim určitě šla. Já jsem $v$ tomhle taková drzá. Šla bych se ho zeptat, co se děje. Neudělala bych to určitě takhle na začátku, udèlala bych to až ted' ke konci roku, ale obecně já jdu za tím učitelem a zeptám se. Já jsem v tomhle aktivní a jdu se ho zeptat, zda něco nepotřebuje nebo jestli je v pohodě. Pokud se vyučující odhodlá s daným tématem svěřit, školní psycholog se snaží co nejvíce nastalou situaci zmapovat (co už dotyčný vyzkoušel, kdy se cítí nejhůře apod.) a poté se snaží společně hledat řešení. At' už je řešení jakékoliv (odchod ze školy, změna třídy, nemocenská, ...), školní psychologové podpoří dotyčného v jeho nejlepším zájmu. V rozhovorech zaznívaly i specifické postupy při řešení syndromu vyhoření. Tím bylo např́íklad sepsání si seznamu pro a proti ve své práci, dále také snaha orientovat vyučující na pozitivní zdroje v jejich životě (rodina, zájmy apod.) či snaha odlehčit jim v náročných situacích. To popsala např́klad Lenka: Aby si toho nebrali tolik a aby to hlavně všechno neřešili a zkusili se na něco fakt vykašlat, že jim to za to nestojí a že na to mají právo.

Ačkoliv všichni informanti v rozhovorech popisovali určité preferované postupy práce s vyučujícími vykazujícími projevy syndromu vyhoření, ve většině př́padů se jednalo spíše o hypotetické scénáře. Ve dvou př́padech proto, že riziko vyhoření vůbec nepovažovali na škole, kde působí, za relevantní; v dalších čtyřech prrípadech proto, že i když identifikovali u části pedagogického sboru projevy vyhoření, charakter vztahu s vyučujícími nedovoloval realizovat potřebné intervence. Jen v pěti př́padech měli školní psychologové reálné zkušenosti s řešením syndromu vyhoření u vyučujících na vlastní škole.

\section{Diskuze a závěr}

Prezentovaná studie zjišt'ovala, jak školní psychologové uvažují a pracují v oblasti učitelského vyhoření. Zaměřovala se přitom hlavně na oblast prevence a řešení syndromu vyhoření. Projevy syndromu vyhoření informanti spatřovali především ve vyčerpanosti, podrážděnosti, ztrátě nadšení a somatických obtížích. Jedná se o manifestace syndromu vyhoření na třech úrovních - psychické, fyzické a sociální, což odpovídá vymezení syndromu vyhoření podle Mezinárodní klasifikace nemocí (MKN-11) i podle výzkumných nálezů (např. Kebza \& Šolcová, 2003; Maslach, Jackson \& Leiter, 1996).

Celkově oslovení školní psychologové vnímali syndrom vyhoření jako reálný problém $\mathrm{v}$ českých školách, a to proto, že učitelství je podle nich obecně velmi náročné povolání a míra zátěže se v posledních letech zvyšuje $\mathrm{z}$ důvodu nadbytečné administrativy, nízké prestiže a častějšímu kontaktu s náročnými žáky či rodiči. Přesvědčení našich informantů tak odpovídá nálezům z výzkumů učitelského vyhoření. Například nejnovější český výzkum zjistil, že zhruba $1 / 5$ vyučujících vykazuje příznaky syndromu vyhoření a téměř $2 / 3$ vyučujících jsou kvůli zvýšenému stresu ohroženi vznikem vyhoření (Smetáčková et al., 2019). Podobné výsledky naznačují i další zahraniční a české výzkumy (Fontana \& Abouserie, 1993; Poschkamp, 2013; Židková \& Martinková, 2003). Téměř všichni školní psychologové zúčastnění v naší studii 
identifikovali ve svých školách několik vyučujících se syndromem vyhoření; pouze ve dvou př́padech žádný prrípad syndromu vyhoření na vlastní škole nepotkali, avšak i přesto si uvědomovali jeho existenci mezi vyučujícími na jiných školách.

Školy bez vyhořelých vyučujících se vyznačovaly tím, že byly umístěny v menších městech či měly poměrně nízký počet žáků i vyučujících, v pedagogickém sboru panovaly blízké vztahy, a to i se školním psychologem. Právě dobré vztahy v kolektivu pokládali oslovení školní psychologové za hlavní faktor, který ovlivňuje riziko syndromu vyhoření. Pokud ve školách panují dobré vztahy a vyučující si poskytují vzájemnou kolegiální podporu, snižuje to jejich stres, a tím je to chrání před vznikem syndromu vyhoření. Naopak nedostatečná podpora a konflikty podle informantů přispívají ke vzniku syndromu vyhoření. Za součást kolegiální podpory byly pokládány také vztahy mezi učitelským sborem a vedením školy, které se projevují v tom, že vedení školy nastavuje pro vyučující funkční organizaci práce, nepřetěžuje je, naslouchá a nabízí jim zastání (především vůči žákům a rodičům). Část podpory může poskytovat také školní psycholog, který pomáhá řešit náročné situace. Důležitost vztahů s kolegy na rozvoj syndromu vyhoření potvrzují zahraniční (Brackett, M. A., Palomera, R., Mojsa-Kaja, J., Reyes, M. R., \& Salovey, P., 2010; Poschkamp, 2013) i české výzkumy učitelských stresorů (Holeček, 2001; Kohoutek \& Řehulka, 2011).

Navzdory tomu, za jak velký problém naši informanti syndrom vyhoření považovali, žádný z nich se ve své praxi na aktuální škole učitelským stresem a syndromem vyhoření specificky nezabýval. Pro zjišt’ování profesní spokojenosti a profesního stresu nevyužívali žádné diagnostické nástroje s tímto zaměřením. V rozhovorech však školní psychologové deklarovali, že atmosféru ve škole nespecificky monitorují a všímají si projevů vyučujících, z nichž mohou usuzovat na to, jak silný pracovní stres zažívají. Pravidelné sledování psychického stavu vyučujících doporučuje např́klad Zelinová (1998), ovšem už se nevyjadřuje k tomu, jak by toto sledování mělo probíhat. Neukotvenost a nestrukturovanost monitorování naznačovaly i výpovědi našich informantů. Zvláště v případě méně zkušených školních psychologů bylo patrné, že by uvítali existenci odborných zdrojů, z nichž by mohli čerpat náměty pro větší systematičnost sběru dat o psychickém stavu vyučujících.

V oblasti prevence syndromu vyhoření zmiňovali oslovení školní psychologové tři druhy aktivit. Prvním byly nespecifické aktivity, kdy školní psychologové přispívají k prevenci syndromu vyhoření u vyučujících již svým pouhým působením na škole, i když to není primárním cílem. Podle jejich přesvědčení, vědomí možnosti blízké pomoci působí pro vyučující samo o sobě preventivně. Druhým typem aktivit byla nabídka pomoci pro vyučující v zátěžových situacích. Jedná se zejména o individuální konzultace, které informaci považují za stěžejní pro prevenci syndromu vyhoření. Ale také například o „vypůjčování“ náročných žáků z výuky vyčerpaných vyučujících tak, aby nebyla zvyšována jejich zátěž a naopak zažili pocit úspěšně vedené vyučovací hodiny. Třetím druhem aktivit bylo organizování seminářů, výjezdů nebo supervizí, tedy př́ležitostí k získání nových informací, inspirace a odstupu. Zatímco první druh aktivit zmiňovali všichni školní psychologové, stejně tak jako nabídku konzultací, ostatní aktivity uváděla jen malá část informantů. Všechny zmiňované aktivity můžeme najít v odborných publikacích jako doporučení pro náplň školní psychologie. Například Braun, Nováčková a Marková (2014) uvádějí, že školní psychologové mohou být požádáni o přednášku či preventivní aktivitu týkající se učitelského stresu, nebo mohou poskytovat či organizovat supervize pro vyučující. Žádné podrobnější náměty a instrukce však $\mathrm{v}$ této ani $\mathrm{v}$ jiných publikacích nejsou $\mathrm{k}$ dispozici. 
Vedle prevence informanti uváděli, že se snaží pracovat s vyučujícími, které identifikovali jako vyhořelé. Intervenční zásahy u dotazovaných školních psychologů zahrnovaly tyto kroky: osloví je, nabídnou jim pomoc, snaží se zmapovat situaci, společně hledají nejvhodnější řešení a podpoří učitele $v$ jeho nejlepším zájmu. Ve fázi mapování a hledání řešení někteří informanti uváděli využívání specifických postupů, jako je sepsání si pro a proti v práci, snaha orientovat se na pozitivní zdroje v okolí či snaha odlehčit vyučujícím v náročných situacích. Žádné další intervence, napřr. systematické poradenství, relaxační techniky či spolupráce s psychoterapeutem či psychiatrem atd., však v rozhovorech nebyly zjištěny. Až na několik výjimek, byli oslovení školní psychologové přesvědčeni, že v př́ípadě potřeby by se na ně profesně nespokojení nebo vyhořelí vyučující obrátili. Odborná literatura pojednávající o školní psychologii se $\mathrm{k}$ tomuto tématu nevyjadřuje. V odborné literatuře se setkáme pouze s obecnými doporučeními ohledně práce s lidmi se syndromem vyhoření (ne však z pozice školního psychologa) (např. Kebza \& Šolcová, 2003; Poschkamp, 2013; Stock, 2010).

Všichni informanti se shodli, že pro možnou spolupráci s vyučujícími, a to zvláště v oblasti profesního stresu a spokojenosti, je potřeba nejdř́ve vybudovat vzájemnou důvěru. $K$ té podle nich přispívají neformální setkávání, projevování zájmu a vyjadřování respektu vůči vyučujícím. Ale také pomáhá, pokud mají vyučující předchozí pozitivní zkušenost se školní psychologií a pokud považují aktuálně působící osobu na školně-psychologické pozici za sympatickou, kompetentní a časově dostupnou. Na klíčový význam důvěry vyučujících vůči školním psychologům upozorňují všechny publikace, zejména práce Zapletalové (2014). Ta uvádí, že budování důvěry napomáhají neformální setkání, nehodnocení jejich práce, oslovování vyučujících, jejich osobní informování a práce v malých skupinách. Tato doporučení jsou ve shodě s názory a zkušenostmi školních psychologů v naší studii. Výjimku tvoří setkávání se v malých skupinách, která v rozhovorech nebyla uvedena, až na jeden př́pad supervizí.

Naše studie ukázala, že školní psychologové si sice uvědomují vysoké riziko syndromu vyhoření u vyučujících a snaží se vytvářet prostředí, aby vyučující dokázali využít pomoci a podpory, kterou jim nabízí. Nevyvíjejí však žádné specifické aktivity ani pro diagnostiku učitelského stresu a syndromu vyhoření, ani pro jeho specifickou prevenci. Příčiny toho, proč takové aktivity nepoužívají, se vztahovaly ke třem oblastem - 1) k nastavení vztahu s vyučujícími, tj. zda vyučující vědí a věří, že mohou se školními psychology řešit své pocity, 2) k organizačnímu nastavení školně-psychologických služeb, tj. zda školní psychologové mají dostatečně velký úvazek a zadání ze strany vedení školy, aby se ve své práci věnovali také vyučujícím, 3) ke kompetencím školních psychologů pracovat s učitelským stresem a vyhořením, tj. zda školní psychologové znají vhodné diagnostické, preventivní a intervenční postupy a zda mají v této sféře dostatečně vysokou self-efficacy. K odstranění části zmíněných příčin by pomohlo, kdyby v profesní prrípravě školních psychologů, v jejich celoživotním vzdělávání a v odborných publikacích byla větší pozornost věnována práci s učitelskými sbory i s jednotlivými vyučujícími a konkrétním postupům v tématech profesní spokojenosti, profesního stresu a syndromu vyhoření.

Realizovaný výzkum byl kvalitativního charakteru, což znamená, že pracoval s malým výzkumným souborem. To nám umožnilo získat hlubší vhled do působení 11 školních psychologů v oblasti učitelského vyhoření. Vzhledem k velikosti výzkumného souboru nelze však získaná data generalizovat. $\mathrm{K}$ tomu by bylo potřeba realizovat rozsáhlejší výzkum s větším reprezentativním výzkumným souborem. Limitující byl také samotný výběr zúčastněných informantů. Jednalo se o školní psychology, kteří měli zájem o spolupráci na výzkumu, někteří 
z nich se dokonce sami ozvali. Lze tak předpokládat, že se jedná o ty motivovanější a aktivnější ve své práci, tedy o školní psychology, kteří svou práci odvádí „kvalitně“. Další limit vnímáme i ve zvolené výzkumné metodě. I přesto, že má polostrukturovaný rozhovor mnoho výhod, nese s sebou i jistá rizika. Ta spočívají především v omezeném čase na rozhovor, během něhož je potřeba soustř̌edit se na mnoho faktorů (splnění všech témat, reagování na otázky,..). Pro zvýšení validity dat by také bylo vhodné zařadit další výzkumnou metodu (např. dotazník, rozhovory s vyučujícími apod.) (Bartoňová, 2019).

\section{Literatura}

Awa, W. L., Plaumann, M., \& Walter, U. (2010). Burnout prevention: A review of intervention programs. Patient Education and Counseling, 78(2), 184-190.

Bartoňová, A. (2019). Působeni školni psycholožky/psychologa v oblasti učitelského vyhoření. Diplomová práce. Praha: Univerzita Karlova, Pedagogická fakulta. Dostupné z https://is.cuni.cz/webapps/zzp/detail/187275.

Brackett, M. A., Palomera, R., Mojsa-Kaja, J., Reyes, M. R., \& Salovey, P. (2010). Emotion regulation ability, burnout, and job satisfaction among British secondary-school teachers. Psychology in the School, 47(4), 406-417. https://doi.org/10.1002/pits.20478

Braun, R., Marková, D., \& Nováčková, J. (2014). Praktikum školní psychologie. Praha: Portál.

Braun, V., \& Clark, V. (2006). Using thematic analysis in psychology. Qualitative Research in Psychology, 3(2), 77-101. https://doi.org/10.1191/1478088706qp063oa

Čáp, J., \& Mareš, J. (2001). Psychologie pro učitele. Praha: Portál.

Fontana, D., \& Abouserie, R. (1993). Stress level, gender and personality factors in teachers. British Journal of Educational Psychology, 63(2), 261-270. https://doi.org/10.1111/j.20448279.1993.tb01056.x

Hastings, R. P., \& Bham, M. S. (2003). The relationship between student behaviour patterns and teacher burnout. School Psychology International, 24(1), 115-127. https://doi.org/10.1177/0143034303024001905

Holeček, V. (2001). Aplikovaná psychologie pro učitele. Plzeň: ZČU.

Kavenská, V., Smékalová, E., \& Šmahaj, J. (2011). Výzkum v oblasti školní psychologie v ČR. E-psychologie, 5(4), 55-67. https://e-psycholog.eu/pdf/kavenska-etal.pdf

Kebza, V., \& Šolcová, I. (2003). Syndrom vyhoření. Praha: Státní zdravotní ústav.

Kips-Vaughan, D. (2013). Supporting teachers through stress management. The Education Digest, 79(1), 43-46.

Kohoutek, R., \& Řehulka, E. (2011). Stresory učitelů základních a středních škol v České republice (zejména stresory způsobené učitelům žáky). In E. Řehulka (Eds.), School and health 21. Výchova ke zdravi: Podněty ke vzdělávacím oblastem (105-118). Brno: Masarykova univerzita.

Kusák, P., \& Urbanovská, E. (2009). Syndrom vyhoření u učitelů ve vztahu k vybraným determinantám. E-Pedagogium, 9(4), 108-121.

Maslach, Ch., Jackson, S., \& Leiter, M. (1996). Maslach burnout inventory. Palo Alto, CA: Consulling Psychologists Press.

Miovský, M. (2006). Kvalitativní prístup a metody v psychologickém výzkumu. Praha: Grada.

Poschkamp, T. (2013). Vyhoření. Rozpoznání, léčba, prevence. Brno: Edika.

Shirom A., \& Melamed, S. (2006). A comparison of the construct validity of two burnout measures in two groups of professional. International Journal of Stress Management. 13(2), 176-200. https://doi.org/10.1037/1072-5245.13.2.176 
Smetáčková, I., Viktorová, I., Štech, S., Pavlas-Martanová, V., Páchová, A., Francová, V., \& Ptáček, R. (2019). Syndrom vyhoření a jeho souvislosti u vyučujících na českých základních školách. Československá psychologie, 63(4), 386-401.

Smetáčková, I., Vondrová, E., \& Topková, P. (2017). Zvládání stresu a syndrom vyhoření u učitelek a učitelů ZŠ. E-Pedagogium, 17(1), 59-75.

Stock, Ch. (2010). Syndrom vyhoření a jak jej zvládnout. Praha: Grada.

Štech, S., \& Zapletalová, J. (2013). Úvod do školní psychologie. Praha: Portál.

Vágnerová, M. (2005). Školní poradenská psychologie pro pedagogy. Praha: Karolinum.

Vyhláška č. 197/2016 Sb., kterou se mění vyhláška č. 72/2005 Sb., o poskytování poradenských služeb ve školách a školských poradenských zařízeních, ve znění pozdějších předpisů, a některé další vyhlášky (2005). https://www.zakonyprolidi.cz/cs/2016-197.

World Health Organization. (2019). International Statistical Classification of Diseases and

Related Health Problems. https://www.who.int/classifications/icd/en/

Zapletalová J. (2001). Co dělá školní psycholog? Kritická místa profese. Pedagogika. Mimořádné číslo, Aktuálni otázky vzděláváni děti se speciálními vzdělávacími potřebami, 51, 34-46.

Zapletalová, J. (Eds.). (2014). Metodika pro práci školního psychologa zapojeného ve školním poradenském pracovišti. Praha: NÚV.

Zelinová, M. (1998). Učitel' a burnout efekt. Pedagogika, 48, 164-169.

Židková, Z., \& Martinková, J. (2003). Psychická zátěž u učitelů základních škol. České pracovní lékařství, 3, 6-11.

Studie prezentovaná v článku byla finančně podpořena Grantovou agenturou ČR (GA1621302S) a Technologickou agenturou ČR (TL01000399).

\section{O autorkách}

Mgr. Anna Bartoňová pracuje jako školní psycholožka a psycholožka v pedagogickopsychologické poradně. Zároveň je studentkou doktorského studia na katedře psychologie Pedagogické fakulty Univerzity Karlovy.

\section{Kontaktní údaje:}

Adresa: PPP pro Prahu 10, Jabloňová 30a, Praha 10, 10600

E-mail: bartonova@ppp10.eu

Doc. PhDr. Irena Smetáčková, Ph.D. působí na katedře psychologie Pedagogické fakulty Univerzity Karlovy. Ve svých aktuálních výzkumech se věnuje zejména profesní náročnosti učitelství a technikám kolegiální podpory, které zvyšují profesní spokojenost a snižují riziko syndromu vyhoření.

\section{Kontaktní údaje:}

Adresa: Katedra psychologie Pedagogické fakulty Univerzity Karlovy, Myslíkova 7, Praha 1 E-mail: irena.smetackova@pedf.cuni.cz

Bartoňová, A., \& Smetáčková, I. (2020). Učitelské vyhoření v perspektivě školních psychologů. E-psychologie, 14(2), 37-51. https://doi.org/10.29364/epsy.371 